\title{
Policies on language education in Indonesia
}

\author{
Fuad Abdul Hamied* and Bachrudin Musthafa \\ Department of English Education, Faculty of Language and Literature Education, Universitas Pendidikan Indonesia, \\ Jl. Dr. Setiabudhi No. 229 Bandung, West Java, Indonesia
}

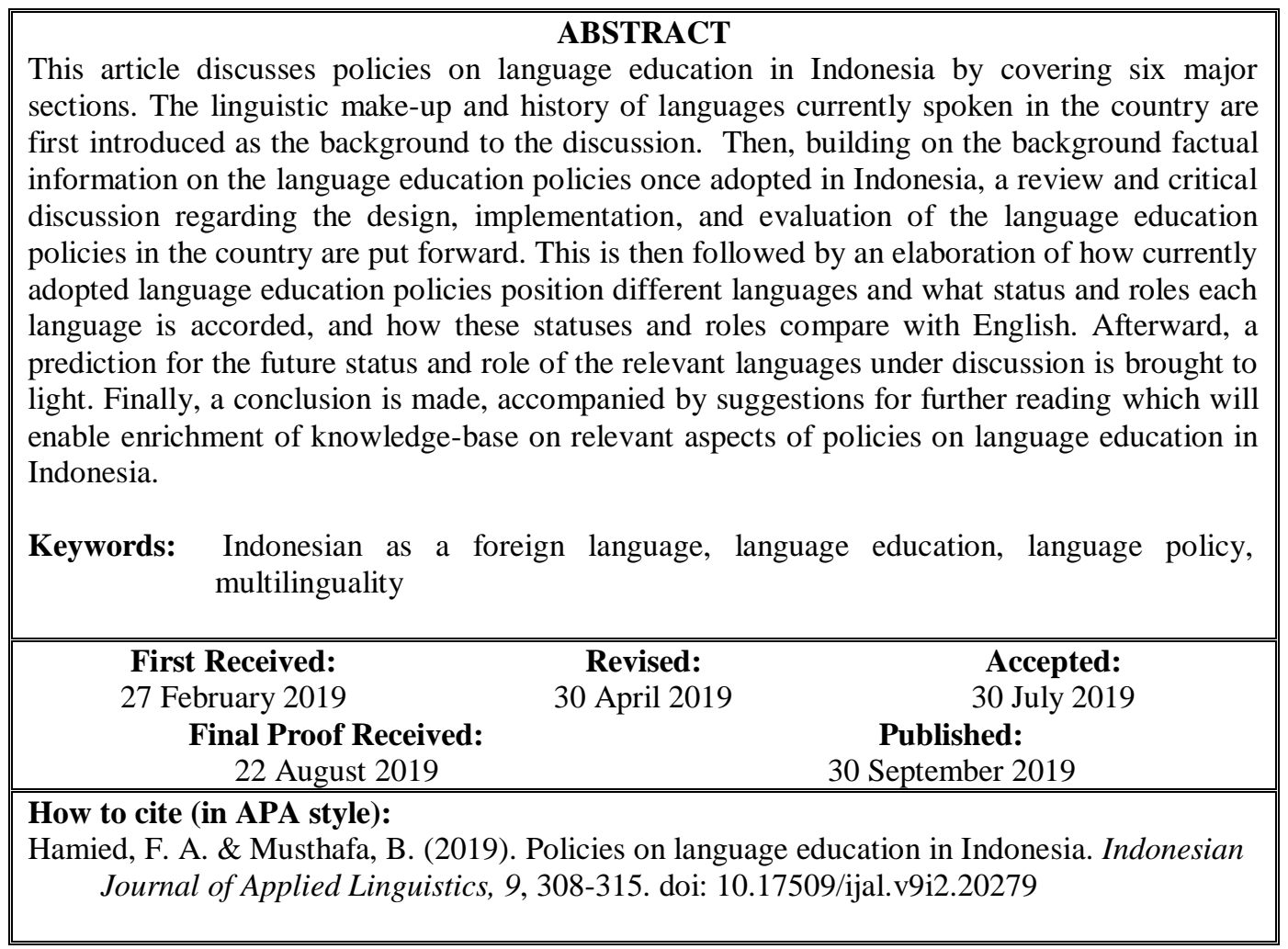

\section{INTRODUCTION}

Scholars such as Hubner (1999), Kam and Wong (2004), Spolsky (2004; 2009) Tollefson (2013), and Tsui and Tollefson (2007) have provided definitions of language policy, each emphasizing some selected aspects, depending upon the language policy perspective adopted, different from what the others do. Weinstein (1990) has suggested that language policy and political development represents an intertwined entity. Talking specifically about language planning, Weinstein further maintains that language planning can serve at least three different purposes: to maintain the status quo, to reform, and to transform. Following Weinstein's ideas as a reference, this article discusses policies on language education in Indonesia by covering six major sections. First, background information on Indonesia which explains the linguistic make-up of languages currently spoken in the country. Building on the background factual information on the language education policies once adopted in Indonesia, the next section reviews and discusses the design, implementation, and evaluation of the language education policies in the country. This is followed by a review and discussion on how currently adopted language education policies position different languages and what status and role each language is accorded, and how these statuses and roles compare with those of English. Some contextual and pedagogical intricacies are put forward, and ensuing from here with a prediction for the future status and role of Indonesian as a foreign language. The last part is a conclusion with suggestions for further readings, which could enrich knowledge base on relevant aspects of policies on language education in Indonesia.

\section{BACKGROUND}

Indonesia has a great size of population presently estimated to reach almost 250 million people, inhabiting numerous islands. Often referred to as an archipelago

\footnotetext{
* Corresponding Author

Email: fuadah@upi.edu
} 
country, Indonesia consists of a significant number of distinct ethnic groups, speaking hundreds of languages (Paauw, 2009; Renandya, 2000). The latest statistics have indicated that there are now over 700 living languages in the archipelago (Lewis, Simons, \& Fennig, 2013 cited in Cohn \& Ravindranath, 2014).

Unlike other multilingual nations such as India and The Philippines which have experienced socio-political problems associated with the adoption of a single national language, Indonesia has been extremely successful in its national language policy-making. Early on in its history as a nation-state, Indonesia took Bahasa Indonesia (BI) - initially a variety of Malay_as its national language. The adoption of Bahasa Indonesia as the national language for this archipelago country was made public on the historic event of the First Congress of Indonesian Youth in 1928 and was later further solidified when the first language congress was held in 1938. This congress marked the beginning of formal language planning activities for the development of Bahasa Indonesia as a distinct language of Indonesian people (Paauw, 2009).

The status of Bahasa Indonesia as the state language was explicitly formalized in article 36 of the 1945 Constitution (Simanjuntak, 2009). Consistent with its status as the national language, Bahasa Indonesia serves at least four functions: (1) as a symbol of one's affiliation with Indonesia as a nation-state; (2) as a bearer of national identity as Indonesian people; (3) as a tool for unifying tribes and communities that have different cultures and languages; and (4) as a functional means for cross-cultural communication within the archipelago. In its function as the official language, the Indonesian language serves the roles as (1) the official state language, (2) the social medium of instruction in educational institutions, (3) the official language for communication at the national level in social and governmental affairs, and (4) the official language for the development of culture and the use of science and technology.

Aside from Bahasa Indonesia as the national, state language for Indonesian people as a whole, there are other two big categories of language in Indonesia: the vernaculars and foreign languages (Alwi \& Sugono, 2011). These language categories will be discussed in the ensuing sections.

\section{EARLIER LANGUAGE EDUCATION POLICIES}

As observed by Hamied (2015), Indonesia as a nationstate has updated its language policies in a series of historical meetings and conferences since the early years around the country's proclamation of independence in 1945. Moeliono (1981) has the specific information. The first Language Congress took place in Surakarta in 1939, initiated by Poedjangga Baroe (The New Poets), and resulted in an idea to make Bahasa Indonesia the official language and as the medium of communication in representative bodies, in courts, and also in legal documents. The second Language Congress was held in 1954 and stipulated that language policy should regulate the status and the mutual relationship among the Indonesian language, local languages, and foreign languages. The Third Language Congress was held in 1978 by the National Language Center in Jakarta and resulted in an agreement that a congress which specifically addresses the issues of national culture be convened. With regard to language development, it was agreed that an established and norm-based grammar should be put as a priority agenda.

If we consider the Indonesian wider political context, these series of national congresses and language policy-making happened in the so called "Old Order" and "New Order" eras, when power management was nationally centralized. It was the period which covered the first language congress (1938) to the fifth congress in 1988. During the period from 1938 to 1988 - that is 50 years - the language policies can be summarized as follows (Hamied, 2015; Idris 2014; Renandya, 2000).

Bahasa Indonesia. Initially considered as a variant of Malay language, by political decree, Bahasa Indonesia was declared as the national language of Indonesia in a historical political event of Youth Pledge ("one land, one nation, and one language"-Paauw, 2009). Bearing unparalleled historical significance for the Indonesian people, Bahasa Indonesia was accepted as the official language of this archipelago and multilingual country. During the Old Era regime of President Soekarno between 1959 and 1966, the basic principles of Indonesia's language policy were established and implemented gradually to replace the Dutch after the most Dutch-language schools were closed as a part of nationalization agenda in early 1950s. As the use of Dutch in schools decreased, the role of Bahasa Indonesia became more dominant in the education setting. During this period of Old Era, local languages were protected by the constitution, and foreign languages - especially English —enjoyed the status as a subject matter taught in schools.

Renandya (2000), citing authorities such as Nababan (1982) and Poedjosoedarmo (1981), has observed that Bahasa Indonesia is generally used for "high" speech functions such as official communications and instruction in schools and universities, while vernaculars are usually used for "low" speech functions such as conversations with family members and close friends. Additionally, for communication across different ethnic groups, Bahasa Indonesia also functions as a language of communication for current and modern topics such as business transactions, films, music, modern dramas, formal speeches, advertisements, newspapers, and magazines. With a wide range of pragmatic functions such as these ones, Bahasa Indonesia enjoys a great deal of acceptance and wide use among most educated social groups in Indonesia.

Consistent with its functions as the national language as stipulated in the national language policy (see, e.g., Alwi \& Sugono , 2011), Bahasa Indonesia 
has been used as the medium of instruction both in private and public schools and at all levels of education throughout the archipelago, from elementary schools to higher learning institutions. In addition to its role as the language of instruction, Bahasa Indonesia is also taught as a compulsory subject at all levels of education. In elementary schools Bahasa Indonesia is taught approximately 5 hours of contact per week for all six years. For junior and senior secondary schools, Bahasa Indonesia is taught at least 4 contact hours per week for all six years. Students who are in the language stream are taught more Bahasa Indonesia: 10 contact hours per week (Muslich, 1994 cited in Renandya, 2000). At the university level, Bahasa Indonesia is also offered as a compulsory subject, being taught one to two hours per week for one or two semesters depending on the policy of each university.

Renandya (2000) has noted following Muslich (1994) and Nababan (1982) that there are two major goals of instruction of Bahasa Indonesia in schools: (1) to develop competence in the language, and (2) to foster the feeling of nationalism and unity as citizens of Indonesia. While the instructional goals are sensible, however, there are no large-scale measures that can be used to assess the relative success of the instruction (Renandya 2000, p. 120). In the absence of reliable assessment tools, one can only speculate. One example of such a speculation - presumably reasoned one- has come from Moeliono (2011, pp. 134-135). He argues that successful teaching of the Indonesian language depends to a large extent on the quality of the instructors. Currently there are only about 17 percent of teachers of Bahasa Indonesia who have met the required qualification. It stands to reason than that results of the teaching of Bahasa Indonesia in schools are always under expectation.

What was the purpose of teaching foreign languages - especially English in the past eras? The status and functions of foreign languages - and English in particular-have remained the same since the "Old Order" and "New Order". According to Renandya (2000) the aim of English instruction in Indonesian schools has not changed much since 1967. Specifically, according to the curriculum adopted in the 1960s and 1970s, the aim of English instruction in Indonesia's schools was to develop in students relatively adequately reading skills to engage in science-related texts written in English. So reading skills were taken as a priority, although it did not mean that the other three linguistic skills (i.e., listening, speaking, and writing) were neglected.

Renandya (2000) has noted that since 1945 up to sometime before Reform Era was initiated, no fewer than six teaching methods have been nationally prescribed: grammar translation, direct method, oral approach, audio-lingual method, communicative approach, and, more recently, the meaning-based approach (p.124).

How were the results of English teaching during those two eras? Again, we do not have written records on this. This, again, has invited some speculations. As an example, this is one assessment from Moeliono (2011): "as there are less than 20 percent of teachers of English have the qualification to teach the language properly, we can only expect that the majority of high school graduates lack the abilities to use English" (p.135).

\section{CURRENT LANGUAGE EDUCATION POLICIES}

Reform era in Indonesia, which began in 1999, has brought with it a decentralization of educational management. This change in how educational matters are managed has been consequential both in terms of policy-making as well as policy implementation. With a focus on English language teaching, Hamied (2015) has eloquently introduced the issues of language teaching amidst the intricate context of the Indonesian language policy. He has clearly delineated that language policies in the multilingual context of Indonesia are an intricate phenomenon. He has observed that using an established mechanism in the forms of a series of gatherings, national language congresses have taken place where prominent experts from various fields of specialization and practitioners of all walks of life meet and discuss important things in the seminar agenda. Language policies in Indonesia have been articulated in different fora and reviewed from time to time. The existing policy has been made responsive to new challenges and development that occur in the current Indonesian linguistic scene. Foreign languages-especially English - are recognized as an indispensable tool in global competition and cooperation and for science and technology as well as for other human interaction activities.

In the early days of the beginning of Reform era in 1999, we began opening up possibilities by questioning practically almost anything thinkable. The Language Policy Seminar held in Cisarua, Bogor, Indonesia on November 8-12, 1999 considered a comprehensive range of linguistic and literary matters, embracing problems regarding the Indonesian language and literature, local languages and literature, and foreign languages.

Later national congresses recommended that the National Language Center be upgraded to become an institution equivalent in authority to a Directorate General, reporting directly to the Minister of National Education. In 2011, the Center turned into such an institution called Badan Pengembangan dan Pembinaan Bahasa (Hamied, 2015).

With this newly established "language development center," some new unprecedented expectations have emerged. In the ninth national language congress, it was decided that through $B I P A$ (The Indonesian Language for Speakers of Other Languages) teaching programs, Bahasa Indonesia should be introduced more systematically and aggressively to the global communities - that is, through BIPA the Language Development Center is expected to create and develop linkages to neighboring 
countries in Asia and beyond. At the time when this manuscript was prepared in late February 2018, the second author of this article received informal news from the Director who is responsible for developing $B I P A$ that during that year alone, the Center had made decision to send 27 instructors of Bahasa Indonesia to various countries which have diplomatic relation with Indonesia.

While this "BIPA Going Global" initiative is commendable, the challenges in the language education policies in Indonesia prevail. The test for policies is in their implementation. And to get to this stage, empirical research at a large scale should be rigorously carried out at a regular interval--before policy-making, during policy implementation, and after the policy is implemented empirically.

With this awareness raising mission, it is good to check - at this point — what observers have to say on how three categories of languages (Alwi \& Sugono, 2011) have been treated and with what results. In their republication of the results of a national seminar on languages in Indonesia once published in 2003, Alwi and Sugiono (2011) have made an invaluable effort to make accessible to a wider readership reference materials on Seminar on Language Politics held in Cisarua, Bogor, West Java, November 8-12, 1999. The year of 1999 marked the beginning of reform era in the history of Indonesia where regional autonomy was unprecedentedly passed down to the level of regency. In this volume, basic principles of national language policies are explicitly articulated covering policies for national language (Bahasa Indonesia), regional languages, and foreign languages. There are also fruitful discussions in this publication regarding stipulations associated with the status and functions of various languages: Bahasa Indonesia (BI) as the national language and as the state language; the vernaculars, and foreign languages together with how each should be developed, maintained, and socialized by teachinglearning activities in schools. And implementation of each stipulation should be managed by a robust institution. Hence, as has been mentioned above, there came the establishment of the Language Development Center, whose chair directly reports to the top ministerial leader, i.e. the Minister of Education and Culture.

The Language Development Center has indeed been charged with the formulation, implementation, and evaluation of Indonesia's language policy, as has been underlined by Renandya (2000). He has diligently pulled together relevant materials from the past and some of them have come from difficult-to-reach places. In an article entitled "Indonesia," Renandya (2000) has explored and delineated very crucial topics under seven sections which cover discussion of Indonesia's geographic and demographic data as well as wellpresented patterns of policy-making related to language education. He also discusses in an eloquent presentation the issues of the status and functions of important languages available in Indonesia. The background of national language policy-making was also presented in a very reader-friendly way. Language in educationwhich is the core topic of our article-was discussed with historical data-based support presented in a very flowing way. In addition, the prognosis for future development was charted out carefully without blatant-and generally erroneous-overstatement nor understatement.

As mentioned earlier, there should be empirical research-at a large scale-rigorously carried out at regular interval before policy-making, during policy implementation, and after the policy is implemented empirically. With this awareness raising mission of this article, it is good to check-at this point-what observers have to say on how three categories of languages (Alwi \& Sugono 2011) have been treated and with what results.

First, the teaching of Bahasa Indonesia. During the current "Reform Era", the teaching of Bahasa Indonesia has witnessed excessively frequent curricular changes in Indonesia's educational context including the adoption of "competency-based curriculum", "school-based curriculum", the 2013 curriculum, and the "genre-based curriculum". All these "academic experimentations" were initiated by policy makers at the central office in Jakarta but without proper follow-up activities-- making anybody in the field of language education and/or curriculum development unable to comment on their relative merits and/ or demerit. This lack of adequate records on national-scale policy-implementation has invited speculations from educational commentators. Mining ideas from several key figures in the language education in the country including Dardjowidjojo (2000), Nababan (1991), Sadtono (1997), and Hamied (1997), Renandya (2000) has the following observation:

The problem concerning the teaching and learning of English is a complex one, and it is not easy to pinpoint the real cause for its lack of success. However, of the many problems facing English teaching in Indonesia, language educationists attribute the generally low English proficiency among Indonesians to factors such as large classes (40 to 50 pupils), meagre instructional resources, poor teacher salaries, limited number of teaching hours, etc. These are...problems that are "the teacher's capability to surmount". Solution to these problems necessitate a reformulation of the national foreign language policy (p.123).

Second, the teaching of vernaculars. Researchers in resource-scarce countries like Indonesia would readily attest to the fact that funding providers are usually interested in funding "world priority" topics which are generally expected to impact on the global world. This way of thinking will push away proposals of research whose foci are on learning and teaching of vernaculars. Like it or not, preference - albeit probably subconsciously_over the trends of issues being promoted by international funding agencies will bring inequality of attention from researchers and policy makers alike. But this tendency is not a script carved on stone which is difficult to change. 
We have observed that present-day leaders in the Ministry of Education and Culture have for a quite sometimes been recruited by the office of Minister of Education in Jakarta on a competitive basis. One very likely basic consideration includes academic productivity and currency of ideas. Building on this professional belief, we have confidence that university professors, educational researchers, and policy-makers in the bureaucracy can think over the research priorities to ensure the biggest benefits for the public.

After some deliberations on the research topics considered of high priority in the field of mother-tongue (or vernaculars) research are carried out "objectively", the list of priority topics can be developed together with timeline and funding allocation. If the implementation of the agreed-upon research schedules should be commissioned from some specific research/or consulting agencies, caution should be exercised to ensure that the biggest public interest is kept assured.

Third, the teaching of foreign languages especially English. There are several foreign languages recognized and in effect given a place in Indonesia's schools. These include English. Additionally, there are also other foreign languages taught in Indonesia's schools: Arabic, French, German, Japanese, Chinese, Korean, and other languages. Each language has its own significance to be taught for the benefits of our learners. The teaching and learning of these foreign languages should be improved from time to time. For this purpose, research activities should be carried out rigorously on a regular basis, especially when we take into account the size of student population that we need to take care of in our schooling system and when we have to take every benefit out of the industrial revolution due to unprecedented, disruptive changes and rapid development in innovative technologies.

\section{CONTEXTUAL AND PEDAGOGICAL INTRICACIES}

The linguistic context of Indonesia is intricate indeed. Over 700 living languages, not dialects or varieties, are spoken in this archipelago. Many of those languages are used daily by more than one million speakers: Indonesian, Javanese, Sundanese, Madurese, Minangkabau, Musi Malay, Bugis, Banjarese, Acehnese, and Balinese (Lewis et al., 2013 cited in Cohn \& Ravindranath, 2014). The Indonesian language is the official language, which is again in constant contact with the more than 700 local languages above, which in turn creates varieties of the Indonesian language throughout the country. The Indonesian language in Indonesia is in a similar position as compared to the status of English in the world. Hence, we are confronted with world Englishes, in the plural form.

In addition, population-wise, Indonesia is one of the biggest countries in the world. Thus, our linguistic mapping becomes more complex as users of Indonesian and some of the local languages keep increasing in number, plus mobility of the people due especially to economic pressure, which contributes to the complexity of linguistic mixing, blending, and interference. Linguistic tolerance is at stake here. The current population of Indonesia is 271,298,498 as of Monday, September 23, 2019, based on Worldometers elaboration of the latest United Nations data. This will certainly contribute to the more intricate handling of the size of schooling population in the country (https://www.worldometers.info/world-population/ indonesia-population/).

In confronting the issue of existing varieties of the Indonesian language, we have learned a lesson from the context of English as a lingua franca, which emphasizes more on effective cross-cultural understanding and interaction. And the handling of English as a lingua franca, especially in the classroom, is not so much a matter of rectifying pronunciation and intonation as a matter of improved intelligibility and a matter of effective communication. These are the living principles to follow by our foreign language teachers in teaching the target language. Davis (2010) talks about inclusivity as an important ingredient in facing existing Englishes. Certainly, inclusivity should be utilized as well when confronting the many varieties of the Indonesian language.

Effective interaction and improved understanding are two key issues in use of Englishes. As a consequence, identifying similarities and commonalities is more helpful than finding differences among language varieties. We have been reminded to be aware of the inevitability issue and social forces in the development of new varieties, and of the fact that languages and speakers must be flexible and adaptable to succeed in a fast-paced world. It is certainly more fruitful for language teachers to pay more attention to how people succeed in communicating regardless of variability, and to spend less time wondering about the failure of other people to talk as the native speakers of the target language do. It has been shown in our daily life with languages that linguistic diversity and the status of particular varieties of the language are so latently affected in an intricate way by race, class, culture, and, above all, by historical circumstances. Therefore, in a multiethnic, multicultural, and multilingual society, like Indonesia, valuing varieties is a sine qua non, a necessity, an indispensable way of living. And this certainly is true to the world of Englishes as it is true as well to the varieties of the Indonesian language as they are spoken throughout the country by the Indonesian people with different language backgrounds.

As to the question of why we need to be serious about English, we see the reality world-wide that there are more than one thousand million speakers (native and non-native) of English. Therefore, English is the most widely-spoken language in the world. According to Anil (2019), there are 378 million native speakers i.e. those who speak English as their first language and 743 million non-native speakers i.e. those who speak English as their second language in the world. In 
addition, the statistic shows that English belongs to one of the most common languages on the internet, by share of internet users. As of April 2019, English was the most popular language online, representing 25.2 percent of worldwide internet users. In this regard, the teaching of foreign languages, especially English, in Indonesia has to take into account also of the Indonesian people's access to the internet with current Internet users (2019) of above 170 million.

With tremendous advancement of information and communication technology, exposure to English becomes daily phenomena; and therefore, learning the language could automatically be enhanced. Take the birth of the Internet which has now emerged to dominate many of our lives, notwithstanding, the negative impacts on social behaviors against local values which could come up onto the surface. What do all these mean to teachers of English in the country? Certainly knowlegeability on the part of the teachers of both acquired and target languages and cultures, plus the very skills in taking every benefit out of the current advancement in technology. In this respect, an English teacher in Indonesia has the benefit of living in the diverse cultures and therefore could naturally have better familiarity with features of diverse cultures. The next step is to get him/herself introduced to the culture(s) of the English(es) speaking countries.

The importance of English has been clearly indicated in The 1945 Constitution. In its Preamble, it is explicitly underlined that among the goals of establishing the country are to form a government of the state of Indonesia which shall protect all the people of Indonesia and their entire native-land, in order to improve the public welfare, to advance the intellectual life of the people and to contribute to the establishment of a world order based on freedom, abiding peace and social justice. We could only advance our intellectual life by accessing resources, which are mostly through a foreign language. At the same token, our contribution to the world peace would only be enhanced by our ability to communicate with other people using an international language.

From a somewhat different perspective, in article 32 of the constitution, it is stated that the State shall advance the national culture of Indonesia by guaranteeing the freedom of the people to cultivate and develop their cultural values. The State shall respect and cultivate regional languages as a national cultural treasure. When this constitutional article is implemented, then language maintenance is to be enlivened. Maintaining the Indonesian language and all existing local languages could in many ways be counterproductive with respect to foreign language learning. This is the intricate part of the language policy implementation. A good example is the Law 24/2009 on language, flag, the great seal, and the national anthem, which has given prominence to the status of the Indonesian language as a national, official language to be used throughout the country. The regulation is meant to strengthen the unity and oneness of the nation. The
Indonesian language as set forth in Article 28 shall be used in official speeches by President, Vice President, other state officials delivered in the country and abroad.

Another example is what has been stipulated in the Law on the national education system. As regards educational settings as stipulated in Law 20/2003 article 33 , it has been clearly stated that the Indonesian language as the state language shall be used as a language of instruction and that a foreign language could "only" be used as a language of instruction in a certain educational setting to support the ability of a student in the foreign language. Proponents of foreign language use in the classroom would say that there is a sufficient outlet here in the Law for a foreign language use in the teaching-learning process, and in any related teaching-learning activities, including the writing of a master's thesis and doctoral dissertation at the graduate school in Indonesia.

In the context of the country's competitiveness, foreign language teachers in Indonesia should also realize that they belong to the global community. The era of globalization is characterized by integration of the world by economics, communications, transportation, as well as politics. We are to realize as well that we live and work in a global marketplace of goods, services, and ideas, with all pluses and minuses, if any, in the industrial revolution 4.0 era, towards the Society 5.0. As a result, we are confronted with a challenge to produce school graduates, competent not only to function professionally, but also sufficiently equipped to make different facets of decisions as citizens of international society. Transactional and communicative ability, as indicated by Lengkanawati (2019), is indeed an important asset to compete in the industrial era 4.0.

\section{FUTURE POSSIBILITIES REGARDING PLACE, STATUS, AND ROLES OF INDONESIAN AS A FOREIGN LANGUAGE}

Commentators and senior educationists whose opinions were cited and discussed in previous sections seem to have no strong confidence about the prospects of language education policies in Indonesia. We, writers of this article, however have a sense of future development for the benefits of the archipelago country called Indonesia.

Although prognosis for a better future may seem "blurred" at this point, the idea of supporting the "BIPA-Going Global" initiative has some potentials for success in the future. Some obvious reasons follow.

(1) A number of foreign-language proficient Indonesian BIPA instructors have accumulated by now from experience in the past few decades. We need to check their academic qualifications and BIPA-teaching experiences. This intellectual capital should be carefully documented and rigorous and systematic plans should be developed to prepare the human capital to become seed human resource for future development. 
(2) In the meantime, BIPA as a field of expertise should be systematically codified and further developed so that systematic training of BIPA teacher candidates can be made and developed.

(3) Research resources should be made available for developing BIPA and the BIPA training program can be developed by way of doing systematic research and development activities so that we have principles to hold on to and research designs to empirically verify for further development.

(4) As research funding might be limited in our ministry, win-win collaboration research and development schemes can be devised together with partner countries so that the development of BIPA instruction can be studied and further developed together.

(5) Hundreds of BIPA teachers currently working overseas, including those new recruits being sent abroad in the last two years, are equipped academically with research skills so that they can begin thinking about doing collaborative BIPA research and development in their respective localities with their partners.

(6) We should break our routine way of thinking which has proven ineffective and begin to think out of the box so that new ideas for BIPA teaching and development can proliferate.

\section{CONCLUSIONS}

This article has introduced intricacies of developing language education policies amidst the multilingual and multicultural contexts of Indonesia. In so doing attempts have also been made to portray the historical journey of the nation-state especially in relation to how the government has responded to demands of socio-cultural challenges occurring both within own country and outside. In order to learn from what has happened and what has been experienced socially and empirically, critical reviews and analyses have been done to the sets of language policies in the past and from implementation of the currently running language policies. To address knotty problems identified along the way, a set of ideas have been proposed to begin to search for way out, especially in response to the challenges borne by the industrial revolution 4.0, towards setting up Society 5.0. Finally, for enrichment of knowledge base on relevant aspects of language education policies in Indonesia, we suggest that you peruse Alwi and Sugono (2011), Badan Pengembangan dan Pembinaan Bahasa (2011), Hamied (2015), Idris (2014), and Renandya (2000).

\section{REFERENCES}

Alwi, H., \& Sugono, D. (Eds.). (2011). Politik bahasa: Rumusan seminar politik bahasa. Jakarta: Badan Pengembangan dan Pembinaan Bahasa.
Anil. (2019, September 25). English language statisticsAn exhaustive list. Lemon Grad. Retrieved from: https://lemongrad.com/english-language-statistics/

Badan Pengembangan dan Pembinaan Bahasa (2011). Kumpulan putusan Kongres Bahasa Indonesia I-IX tahun 1938-2008. Jakarta: Kementerian Pendidikan dan Kebudayaan.

Cohn, A. C., \& Ravindranath, M. (2014). Local languages in Indonesia: Language maintenance or language shift? Linguistik Indonesia, 32(2), 131148.

Dardjowidjojo, S. (2000). English teaching in Indonesia. The English Australia Journal, 18(1), 2-30.

Davis, D. R. (2010). The inclusivity of world Englishes. World Englishes, 29(1), 2126. doi:10.1111/j.1467-971x.2009.01622.x

Hamied, F.A. (1997). EFL Program surveys in Indonesian schools: Towards EFL curriculum implementation for Tomorrow. In G.M. Jacobs (Ed.), Language classroom for tomorrow. Singapore: SEAMEO Regional Language Center.

Hamied, F. A. (2013). ELT intricacies within the Indonesian language policy. In T. W. Bigalke \& S. Sharbawi (Eds.), English for ASEAN Integration: Policies and practices in the region (pp. 32-40). IELTS: Bandar Seri Begawan.

Hubner, T.(1999). Sociopolitical perspectives on language policy, politics, and praxis. In T. Hubner \& K.A. Davis (Eds.), Sociopolitical perspectives on language policy and planning in the USA (pp.116). Philadelphia: John Benjamins Publishing Company.

Idris, S.(2014). Language policy and the construction of national and ethnic identities in Indonesia. USChina Education Review, 4(10), 691-705.

Indonesia Population. (Live). Retrieved from https://www.worldometers.info/worldpopulation/indonesia-population/ Accessed on 23 September 2019 at 21.34 .

Kam, H.W., \& Wong, R.Y. (2004). Language policies and language education. ( $2^{\text {nd }}$ edn.). Singapore: Marshall Cavendish.

Lengkanawati, N. S. (2019). Revolusi industri 4.0: Peluang dan tantangan bagi guru bahasa Inggris sebagai bahasa asing. In F.A. Hamied \& K. Komalasari (Eds.) Ilmu pendidikan, pendidikan bahasa dan seni di era revolusi industry 4.0. (pp. 229-246). Bandung: UPI Press.

Moeliono, A. (2011.Kebijakan bahasa dan perencanaan bahasa di Indonesia: Kendala dan tantangan. In Perencanaan bahasa pada abad ke-21: Kendala dan tantangan (Risalah Simposium Internasional Perencanaan Bahasa) (pp. 128-136). Jakarta: Badan Pengembangan dan Pembinaan Bahasa

Nababan, P. W. J. (1991). Language in education: The case of Indonesia. International Review of Education, 37(1), 115-131. doi:10.1007/bf00598171

Number of Internet Users in Indonesia Rises to 171 Million. (2019, June 13). Retrieved from 
https://www.indonesia-

investments.com/id/news/todays-

headlines/number-of-internet-users-in-indonesiarises-to-171-million/item9144. Accessed on 3 Oct 2019 at $07: 41$

Paauw, S. (2009). One land, one nation, one language: An analysis of Indonesia's national language policy. In H. Lehnert-Le Houillier \& A.B. Fine (eds.), University of Rochester Working Papers in the Language Sciences, 5(1), 2-16.

Renandya, W. (2000). Indonesia. In H.W.Kam \& R.Y.L. Wong (eds.), Language Policies and Language Education (pp.113-137), Singapore: Times Academic Press.

Republic of Indonesia Law, Number 20 Year 2003 on the National Education System.

Republic of Indonesia Law, Number 24 Year 2009 on Flag, Language, and the Indonesian Great Seal as well as the National Anthem.

Sadtono, E. (1997). ELT Development in Indonesia: A Smorgasbord. In E. Sadtono (Ed.), The development of TEFL in Indonesia (pp. 1-19). Malang: Penerbit IKIP Malang.
Simanjuntak, R.R. (2009). Bahasa Indonesia: Policy, implementation, and planning. Jurnal Lingua Cultura, 3(1), 11-19

Spolsky, B. (2004) Language policy: Key topics in sociolinguistics. Cambridge, UK: Cambridge University Press.

Spolsky, B. (2009) Language management. Cambridge, UK: Cambridge University Press.

Tollefson, J.W. (2013). Language policies in education: Critical issues ( $2^{\text {nd }}$ edn.). New York: Routledge

Tsui, A.B.M., \& Tollefson, J.W. (2007).Language policy, and the construction of national cultural identity. In A.B.M.Tsui \& J.W. Tollefson (Eds.). Language policy, culture, and identity in Asian contexts (pp.1-24). Mahwah, NJ.:Lawrence Erlbaum.

Weinstein, B. (1990). Language policy and political development: An overview. In B. Weinstein (Ed.) Language policy and political development (pp.121), Norwood, New Jersey: Ablex Publishing Corporation. 